\title{
HUBUNGAN SIKAP DAN TINDAKAN IBU PENGGUNA KB SUNTIK 3 BULAN DENGAN PERUBAHAN SIKLUS MENSTRUASI DI KLINIK Hj. DERMAWATI NASUTION TEMBUNG TAHUN 2017
}

\author{
The Relationship Of Maternal Attitudes And Actions User Kb Syringe 3 Months With \\ The Change Menstrual Cycle In Clinic Hj. Dermawati \\ Nasution Tembung Year 2017
}

\author{
Dalimawaty Kadir ${ }^{1 *}$, Mutia Sari Mardha ${ }^{2}$, \\ ${ }^{1}$ Dosen D3 Kebidanan Akademi Kebidanan Helvetia, Medan, Indonesia \\ ${ }^{2}$ Dosen D3 Kebidanan Akademi Kebidanan Helvetia, Medan, Indonesia \\ *Penulis Korespondensi Email: d5waty@gmail.com
}

\begin{abstract}
ABSTRAK
Pendahuluan : Pada akseptor kontrasepsi suntik DMPA terdapat gangguan menstruasi seperti amenore yaitu tidak datang menstruasi pada setiap bulan selama menjadi akseptor KB suntik tiga bulan. Tujuan : ibu memakai kontasepsi suntik untuk menjarangkan anak dan ada sebagian ibu tidak mau hamil lagi . World Health Organization (WHO), kontrasepsi hormonal sebagai salah satu kontrasepsi yang meningkat tajam. Cakupan pasangan usia subur hampir 380 juta pasangan menjalankan keuarga berencana 65-75 juta orang. Metode : Penelitian bersifat survei analitik, yang menggunakan metode cross sectional. Populasi dalam penelitian ini ibu pengguna KB suntik 3 bulan yang mengalami perubahan siklus menstruasi dan tidak mengalami perubahan siklus menstruasi di Klinik $\mathrm{Hj}$. Dermawati Nasution Tembung yaitu berjumlah 35 responden, dan pengambilan sampel dalam penelitian ini menggunkan Accidental sampling. Hasil : Hasil penelitian menunjukkan sikap dan tindakan ibu dengan perubahan siklus menstruasi sebanyak 35 orang, berdasarkan sikap positif sebanyak 20 responden $(57,1 \%)$, dan sikap negatif sebanyak 15 responden $(42,9 \%)$, yang mengalami perubahan siklus menstruasi sebanyak tindakan ibu baik sebanyak 23 responden $(65,6 \%)$, dan tindakan ibu kurang sebanyak 11 responden $(34,4 \%)$, yang mengalami perubahan siklus menstruasi sebanyak 20 responden $(57,1 \%)$, dan tidak ada perubahan siklus menstruasi sebanyak 15 responden $(42,9 \%)$. Penelitian ini menunjukkan banyak yang mengalami perubahan siklus menstruasi. Berdasarkan analisis statistik dengan metode Chi-square dengan tingkat kemaknaan $\mathrm{p}<0,05$ diperoleh nilai ( $\mathrm{p}=0,020)$. Kesimpulan : Maka uji Chi-square diatas diperoleh kesimpulan bahwa ada hubungan sikap dan tindakan ibu pengguna KB suntik 3 bulan dengan perubahan siklus menstruasi. Diharapkan kepada setiap tenaga kesehatan untuk selalu memberikan informasi dan konseling kepada ibu pengguna KB sehingga tinggkat pengetahuan mereka tinggi.
\end{abstract}

Kata Kunci $\quad$ : Sikap, Tindakan dan KB Suntik 3 Bulan dan Siklus Menstruasi

\section{ABSTRACT}

Introduction : On the acceptors of contraception hypodermic DMPA there are menstrual disorders such as amenorrhea that is does not come menstruation on every month for being a three-month injection KB acceptors. Objective: The purpose of the mother wearing a kontasepsi injection for children menjarangkan and there are some mothers do not want to get pregnant again. The World Health Organization (WHO), hormonal contraceptives as one of contraception increased sharply. The scope of fertile age couples almost 380 million couples running keuarga planning 65-75 million people. Method: Research survey of analytical nature, which uses a method of cross sectional. The population in this research is the mother of 3-month injection KB user changing the menstrual cycle and not changing the menstrual cycle clinic Hj. Dermawati Nasution Tembung i.e. totalling 35 respondents, and sampling in this study are either Accidental sampling. Result : The results showed the attitude and actions of the mother with the changing the menstrual cycle as many as 35 people, based on positive attitude as much as 20 respondents (57.1\%), and negative attitudes as much as 15 respondents (42.9\%), changing the menstrual cycle as much as the good mother's actions as much as 23 respondents (65.6\%), and the action of the mother less as much as 11 respondents (34.4\%), changing the menstrual cycle as many as 20 respondents (57.1\%), and no changes in the menstrual cycle as much as 15 respondents (42.9\%). This research shows a lot of changing the menstrual cycle. Based on a statistical analysis by the method of Chi-square with a level of significance of 0.05 obtained values $<p(p=$ 0,020). Conclusion : Chi-square test then the above conclusion that there is a relationship of maternal attitudes and actions user KB syringe 3 months with changing the menstrual cycle. Expected to all health care personnel to provide information and counselling to users so that their knowledge is tinggkat KB.

Keywords $\quad$ : Attitudes, Actions and KB Syringe 3 Months and the Menstrual Cycle 


\section{PENDAHULUAN}

Program ini diharapkan dapat memperbaiki kesehatan dan kesejahteraan ibu, anak, keluarga, dan bangsa, mengurangi angka kelahiran untuk menaikkan taraf hidup rakyat dan bangsa, memenuhi permintaan masyakat akan pelayanan KB dan Kesehatan Reproduksi (KR) yang berkulitas termasuk upayaupaya menurunkan angka kematian ibu,bayi dan anak, serta penanggulangan masalah kesehatan reproduksi,Siklus menstruasi merupakan siklusbulanan yang sering terjadi pada wanitasetiap bulannya, siklus reproduksi wanita memerlukan kirakira 28 hari untukmenyiapkan dan melepaskan ovum pada pertengahan siklus, mempersiapkanlingkungan uterus dan jaringan dari uterus yang dikenal sebagai menstruasi, Siklus menstruasi diatur oleh hormone estrogen dan progesteron. Estrogen dibuat oleh folikel de graaf yang matang.Progesteron dibuat dalam jumlah kecil sebelum ovulasi oleh ovarium dan kemudian dalam jumlah lebih besar sesudah ovulasi oleh corpus luteum (masa glandular yang dibentuk oleh folikel matang setelah pelepasan ovum).Corpusluteum juga menghasilkan hormone estrogen dan progesterone.(1)

Sistem hormon yang diatur di otak, tepatnya di kelenjar hipofisis ini akan mengirim sinyal ke indung telur untuk memproduksi sel telur. Bila sistem pengaturan ini terganggu, otomatis siklus menstruasi akan terganggu. Gangguan pada siklus menstruasi akibat penggunaan kontrasepsi suntik dapat berupa amenorea (tidak haid), menoragia (perdarahan haid yang lebih lama), metroragia (perdarahan di luar haid), spotting atau perdarahan yang berupa tetesan Metode KB hormonal sangat popular yang dapat digunakan dalam waktu yang relatif panjang, terutama dalam penggunaan metode KB suntik, penggunaan kontrasepsi suntik masih banyak dipakai oleh masyarakat karena KB suntik ini sangat efektif, aman, dapat dipakai oleh semua perempuan dalam usia reproduksi serta cocok untuk masa laktasi karena tidak menekan produksi ASI.(2)
Menurut World Health Organization (WHO), kontrasepsi hormonal sebagai salah satu kontrasepsi yang meningkat tajam. Cakupan pasangan usia subur hamper 380 juta pasangan menjalankan keuarga berencana dan 65-75 juta diantaranya terutama di Negara berkembang menggunakan kontrasepsi seperti suntik. Kontrasepsi hormonal yang digunakan dapat memiliki pengaruh positif dan negatif terhadap berbagai organ wanita. Pemakaian kontrasepsi hormonal sebanyak terbanyak adalah kontrasepsi suntik yaiti sebesar 38,3\% dan pil sebesar $37,7 \%$, berdasarkan data yang diperoleh dari dinkes provinsi daerah istimewa Yogyakarta pasangan usia subur didaerah istimewa Yogyakarta jumah peserta KB aktif tahun 2012 sebanyak 429,460 pasangan usia subur (PUS) yang terdiri dari akseptor KB suntik 206,869. (3) Badan koordinasi Keluarga Berencana Nasional (BKKBN) telah melakukan reorientasi reposisi visi program KB berupa "Menuju Keluarga Berkualitas 2015" visi baru ini bereorintasi luas, tidak hanya pendekatan demografi. Dalam visi jumlah anak ideal tidak dibatasi dua, melainkan sesuai keinginan dan kemampuan keluarga. Berdasarkan data dari BKKBN Provinsi Sumatra utara, jumlah peserta KB sebesar 119,961 atau $17,83 \%$ dari PUS yang ada.(4)

Berdasarkan Survei Demografi Kesehatan Indonesia (SDKI) pemakaian metode kontrasepsi suntik 49,1 \% (7733 akseptor), Pil 23,2 \% (3654 akseptor), IUD $11,0 \%$ (1732 akseptor), implant atau susuk 7,6\% (1197 akseptor), MOW 6,5\% (1023 akseptor), kondom 1,6\% (252 akseptor), MOP 0,7 \% (110 akseptor). Berdasarkan data diatas kontrasepsi suntik menduduki peringkat teratas karena keefektifan kontrasepsi suntik mencapai $90 \%$ sampai $100 \%$ dalam mencegah kehamilan, meskipun banyak akseptor yang menggunakan kontrasepsi suntik 3 bulan karena keefektifannya tetapi ada beberapa efek samping yang terjadi yaitu amenorhoe sebanyak $68,6 \%$. (5) 
Pada akseptor kontrasepsi suntik DMPA terdapat gangguan menstruasi seperti amenore yaitu tidak datang menstruasi pada setiap bulanselama menjadi akseptor KB suntik tigabulan berturut-turut.Spotting yaitu bercak bercak perdarahan di luar haid yang terjadi selama akseptor mengikuti KB suntik.Metrhoragia yaitu perdarahan yang berlebihan di luar masa menstruasi.Menorhagia yaitu datangnya darah menstruasi yang berlebihan jumlahnya.(6)

Berdasarkan hasil penelitian dan uraian diatas maka dapat disimpulkan bahwa sebagian besar responden akseptor KB suntik mengalami beberapa perubahan siklus haid setelah menggunakan $\mathrm{KB}$ suntik. Efek KB suntik terhadap siklus menstruasi sering tidak menyenangkan,tetapi tidak terlalu berbahaya dan bukan tanda gejala adanya suatu penyakit. Perubahan siklus menstruasi biasanya padatahun pertama pemakaian KB suntik DMPA yaitu perdarahan berupa bercak bercak(spotting), yang dapat berlang sung cukup lama, jarang terjadi perdarahan ataumenstruasi

\section{METODE PENELITIAN}

Desain penelitian adalah survey analitik , dimana bertujuan untuk mengetahui hubungan sikap dan tindakan ibu pengguna $\mathrm{KB}$ suntik 3 bulan dengan perubahan siklus menstruasi. Waktu yang diperlukan untuk menyelesaikan penelitian ini dinilai dari pengajuan judul, data kepustakaan dan konsul proposal februarijuni 2017. Populasi dari penelitian ini yaitu seluruh ibu yang memakai alat kontrasepsi KB suntik 3 bulan sebanyak 38 orang yang ada d Klinik $\mathrm{Hj}$. Dermawati Nasution Tembung dari bulan januari s/d april 2017. Pengambilan sampel dalam peneliti ini adalah menggunakan Accidental sampling dimana seluruh akseptor KB suntik 3 bulan yang ada di Klinik $\mathrm{Hj}$. Dermawati pada bulan januari s/d april tahun 2017 sebanyak 35 akseptor.Penelitian menggunakan alat ukur yang berupa kuisioner yang disusun sendiri oleh normal. Sedangkan apabila sudah beberapa kali suntikan ulang sering kali bahkan tidak mengalami menstruasi sama sekali. Hal tersebut adalah efek samping yang normal. Siklus haid akan kembali normal setelah 3-6 kali penggunaan KB suntik dihentikan.(7)

Berdasarkan hasil Survei awal yang di lakukan oleh peneliti di Klinik $\mathrm{Hj}$ Dermawati Nasution Tembung Tahun 2017 jam 14:25 pasien datang untuk kb suntik 3 bulan sebelum ibu di injeksi saya bertanya pada ibu tentang perubahan siklus menstruasi, haid ibu datang berapa lama dan dari kapan ibu memakai KB suntik, dari jam 14:20 sampai jam 22:00 Akseptor $\mathrm{KB}$ suntik 3 bulan yang datang 9 orang mengalami perubahan siklus menstruasi.

Berdasarkan latar belakang diatas penelitian merasa tertarik ingin mengetahui dan melakukan penelitian tentang Hubungan sikap dan Tindakan Ibu Pengguna KB Suntik 3 Bulan Dengan Perubahan Siklus Menstruasi di Klinik Hj Dermawati Nasution Tembung Tahun 2017.

peneliti berdasarkan konsep teoritisnya yang diberikan langsung objek penelitian, adapun kuisioner ini berisi pertanyaan

mengenai penggunaan alat kontrasepsi $\mathrm{KB}$ suntik 3 bulan dengan perubahan siklus menstruasi dengan menggunakan data primer. Kuesioner yang dibagikan berupa pertanyaan yang menggali pengetahuan semua ibu yang ber KB suntik DMPA di Klinik Hj Dermawati Nasution Tembung Tahun 2017.

Analisa univariat digunakan untuk mendekripsikan data yang dilakukan pada tiap 23 statistic dari hasil penelitian dan untuk memperoleh distribusi penggunaan alat kontrasepsi KB suntik 3 bulan dengan kejadian perubahan siklus menstruasi. Analisa bivariat digunakan untuk mengetahui hubungan (korelasi) antara 23 statistic bebas pemakaian (independent variable) dengan 23 statistic terikat 
perubahan siklus menstruasi (dependent variable). Untuk membuktikan adanya hubungan yang disignaifikan antara 24 statistic bebas dengan 24 statistic terikat digunakan 24 statistic pvalue ( 0,5 ).

\section{HASIL}

Tabel 1. Distribusi Frekuensi Berdasarkan Sikap Ibu di Klinik Hj. Dermawati Nasution Medan Tahun 2017

\begin{tabular}{ccccc}
\hline \multirow{2}{*}{ No } & \multirow{2}{*}{ Sikap } & \multicolumn{2}{c}{ Jumlah } \\
\cline { 3 - 4 } 1 & Positif & & F & \% \\
2 & Negatif & & 20 & 42,9 \\
\hline & & Total & $\mathbf{3 5}$ & 57,1 \\
\hline
\end{tabular}

Berdasarkan tabel 1 dapat diketahui bahwa distribusi frekuensi dari 35 responden mayoritas ibu yang bersikap positif sebanyak 20 responden $(42,9 \%)$ dan mayoritas ibu yang bersikap negatif 15 responden $(57,1 \%)$.

Tabel 2. Distribusi Frekuensi Berdasarkan Tindakan Responden di Klinik Hj. Dermawati Nasution Tahun 2017

\begin{tabular}{clccc}
\hline \multirow{2}{*}{ No } & \multirow{2}{*}{ Tindakan } & \multicolumn{2}{c}{ Jumlah } \\
\cline { 3 - 4 } & & F & \% \\
\hline 1 & Baik & & 23 & 65,7 \\
2 & Kurang & & 12 & 34,3 \\
\hline & & Total & $\mathbf{3 5}$ & $\mathbf{1 0 0}$ \\
\hline
\end{tabular}

Berdasarkan tabel 2 dapat diketahui bahwa dari 35 responden mayoritas tindakan ibu baik sebanyak 23 responden $(65,7 \%)$ dan minoritas tindakan ibu kurang sebanyak 12 responden $(34,3 \%)$.

Tabel 3. Distribusi Frekuensi Berdasarkan Perubahan Siklus Menstruasi responden di Klinik Hj. Dermawati Nasution Tahun 2017

\begin{tabular}{clcc}
\hline \multirow{2}{*}{ No } & \multirow{2}{*}{ Perubahan Siklus Menstruasi } & J & Jumlah \\
\cline { 3 - 4 } & & 20 & 57,1 \\
2 & Ada Perubahan & 15 & 42,9 \\
\hline \multicolumn{2}{r}{ Tidak Ada Perubahan } & $\mathbf{3 5}$ & $\mathbf{1 0 0}$ \\
\hline
\end{tabular}

Berdasarkan tabel 3 dapat diketahui bahwa dari 35 responden mayoritas ibu ada perubahan siklus menstruasi sebanyak 20 responden
$(57,1 \%)$ dan minoritas ibu tidak ada perubahan siklus menstruasi sebanyak 15 responden $(42,9 \%)$.

Tabel 4. Distribusi Frekuensi Tabulasi Silang Hubungan Sikap Dan Tindakan Ibu Pengguna KB Suntik 3 Bulan Dengan perubahan Siklus Menstruasi

\begin{tabular}{|c|c|c|c|c|c|c|c|c|}
\hline \multirow{3}{*}{ No } & \multirow{3}{*}{ Sikap } & \multicolumn{4}{|c|}{ Perubahan Siklus Menstruasi } & \multirow{2}{*}{\multicolumn{2}{|c|}{ Jumlah }} & \multirow{3}{*}{ D } \\
\hline & & \multicolumn{2}{|c|}{ Ada Perubahan } & \multicolumn{2}{|c|}{$\begin{array}{l}\text { Tidak Ada } \\
\text { Perubahan }\end{array}$} & & & \\
\hline & & f & $\%$ & f & $\%$ & $\mathbf{F}$ & $\%$ & \\
\hline 1 & & 16 & 45,7 & 4 & 11,4 & 20 & 57,1 & 0,005 \\
\hline
\end{tabular}




\begin{tabular}{|c|c|c|c|c|c|c|c|}
\hline 2 & Negatif & 4 & 11,5 & 11 & 31,4 & 15 & 42,9 \\
\hline & Total & 20 & 57,2 & 15 & 42,8 & 35 & 100 \\
\hline
\end{tabular}

Berdasarkan tabel 4 menunjukkan hasil tabulasi silang antara hubungan sikap dan tindakan ibu pengguna KB suntik 3 bulan dengan perubahan siklus menstruasi di klinik Hj. Dermawati Nasution Tahun 2017 dapat diketahui bahwa dari 35 responden mayoritas berada pada kelompok sikap positif sebanyak 20 responden $(57,1 \%)$, yang mengalami perubahan siklus menstruasi sebanyak 16 responden $(45,7 \%)$, dan yang tidak mengalami perubahan siklus menstruasi sebanyak 4 responden $(11,4 \%)$, dan minoritas berada pada kelompok sikap negatif sebanyak 15 responden $(42,9 \%)$, yang mengalami perubahan siklus menstruasi sebanyak 4 responden $(11,5 \%)$, dan yang tidak mengalami perubahan siklus menstruasi sebanyak 11 responden $(31,4 \%)$.

Hasil uji Chi-squere pada tingkat kepercayaan $95 \%$ dengan $\alpha=$ 0,05 di dapatkan nilai $p$ value 0,005 $(p<\alpha)$, sehingga memperlihatkan bahwa ada hubungan yang signifikan antara sikap dengan perubahan siklus menstruasi.

Tabel 5. Distribusi Frekuensi Tabulasi Silang Hubungan Sikap Dan Tindakan Ibu Pengguna KB Suntik 3 Bulan Dengan perubahan Siklus Menstruasi.

\begin{tabular}{|c|c|c|c|c|c|c|c|c|}
\hline \multirow{3}{*}{ No } & \multirow{3}{*}{ Tindakan } & \multicolumn{4}{|c|}{ Perubahan Siklus Menstruasi } & & & \multirow{3}{*}{$\boldsymbol{P}$} \\
\hline & & \multicolumn{2}{|c|}{$\begin{array}{c}\text { Ada } \\
\text { Perubahan }\end{array}$} & \multicolumn{2}{|c|}{$\begin{array}{l}\text { Tidak Ada } \\
\text { Perubahan }\end{array}$} & \multicolumn{2}{|c|}{ Jumlah } & \\
\hline & & f & $\%$ & f & $\%$ & $\mathbf{F}$ & $\%$ & \\
\hline 1 & Baik & 17 & 48,5 & 6 & 17,1 & 23 & 65,6 & 0,016 \\
\hline 2 & Kurang & 3 & 8,7 & 9 & 25,7 & 12 & 34,4 & \\
\hline & Total & 20 & 57,2 & 15 & 42,8 & 35 & 100 & \\
\hline
\end{tabular}

Berdasarkan tabel 5 menunjukkan hasil tabulasi silang antara hubungan sikap dan tindakan ibu pengguna KB suntik 3 bulan dengan perubahan siklus menstruasi di klinik Hj. Dermawati Nasution Tahun 2017 dapat diketahui bahwa dari 35 responden mayoritas berada pada kelompok tindakan baik sebanyak 23 responden $(65,6 \%)$, yang mengalami perubahan siklus menstruasi sebanyak

\section{PEMBAHASAN}

Hubungan Sikap Dengan Perubahan Siklus Menstruasi Pada hasil pengelolahan diperoleh bahwa dari 35 responden berada pada sikap positif sebanyak 20 responden, yang mengalami perubahan siklus menstruasi sebanyak 16 responden, dan yang tidak mengalami perubahan siklus menstruasi
17 responden (48,5\%), dan yang tidak mengalami perubahan siklus menstruasi sebanyak 6 responden $(17,1 \%)$, dan minoritas berada pada kelompok tindakan kurang sebanyak 12 responden $(34,4 \%)$, yang mengalami perubahan siklus menstruasi sebanyak 3 responden $(8,7 \%)$, dan yang tidak mengalami perubahan siklus menstruasi sebanyak 9 responden $(25,7 \%)$.

sebanyak 4 responden, dan berada pada sikap negatif sebanyak 15 responden, yang mengalami perubahan siklus menstruasi sebanyak 4 responden, dan yang tidak mengalami perubahan siklus menstruasi sebanyak 11 responden.

Hasil uji Chi-squere pada tingkat kepercayaan 95\% dengan $\alpha=0,05$ di 
dapatkan nilai $p$ value $0,005(p<\alpha)$, sehingga memperlihatkan bahwa ada hubungan yang signifikan antara sikap dengan perubahan siklus menstruasi

Hal ini sejalan dengan Prita (2013) menunjukkan bahwa sikap ibu terhadap efek samping $\mathrm{KB}$ suntik 3 bulan di Desa Bakalanrayung Kecamatan Kudu Kabupaten Jombang diperoleh gambaran bahwa dari 76 responden KB suntik 3 bulan yang mengalami efek samping sebagian besar bersikap positif sebanyak 40 orang.(8)

Pengguna kontrasepsi suntik 3 bulan dengan jangka waktu lama akan menimbulkan terjadinya gangguan menstruasi terutama kejadian amenorhoe sehingga dengan adanya perubahan pola menstruasi bukanlah suatu yang abnormal tetapi suatu efek samping dari lama penggunaan kontrasepsi suntik 3 bulan tersebut.(9)

Hormon progesteron yang terdapat dalam kontrasepsi suntik 3 bulan mempunyai fungsi diantaranya mempersiapkan tubuh untuk menerima kehamilan, sehingga syarat mutlak untuk kontrasepsi dalam implantasi. Hormone progesteron yang ada dalam kontrasepsi suntik 3 bulan menyebabkan endometrium menjadi sekretorik. Dan bilamana progesterone terlalu lama mempengaruhi endometrium maka endometrium menjadi sedikit sekali. Selain itu progesteron membuat lender servik menjadi kental sehingga merupakan barier dari spermatozoa serta mempengaruhi transfor ovum dalam tuba fallopi. (10)

Menurut asumsi peneliti bahwa efek samping bisa berbeda pada setiap individu tergantung dari daya tahan tubuh dan sistem hormon yang ada didalam tubuh masing-masing individu, lama pemakaian KB suntik bisa menyebabkan dinding endometrium menjadi menipis, sehingga semakin lama pemakaian $\mathrm{KB}$ pada responden maka semakin besar pula perubahan siklus menstruasi yang terjadi, khususnya terlebih pada penggunaan kontrasepsi 3 bulan.

Hubungan Tindakan Dengan Perubahan Siklus Menstruasi : Pada hasil pengelolahan diperoleh hasil dari 35 responden mayoritas berada pada kelompok tindakan baik sebanyak 23 responden, yang mengalami perubahan siklus menstruasi sebanyak 17 responden, dan yang tidak mengalami perubahan siklus menstruasi sebanyak 6 responden, dan minoritas berada pada kelompok tindakan kurang sebanyak 12 responden, yang mengalami perubahan siklus menstruasi sebanyak 3 responden, dan yang tidak mengalami perubahan siklus menstruasi sebanyak 9 responden.

Hasil uji Chi-squere pada tingkat kepercayaan 95\% dengan $\alpha=0,05$ di dapatkan nilai $p$ value $0,016 \quad(p<\alpha)$, sehingga memperlihatkan bahwa ada hubungan yang signifikan antara tindakan dengan perubahan siklus menstruasi.

Pengetahuan ibu dalam menggunakan alat kontrasepsi suntik merupakan domain yang penting untuk terbentuknya tindakan ibu dalam menggunakan alat kontrasepsi suntik DMPA. Tujuan yang ibu ketahui hanya sebatas menggunakan alat kontrasepsi suntik agar tidak hamil. Alasan ibu tidak rutin atau datang tidak sesuai jadwal melakukan KB suntik dengan alasan lupa dengan tanggal yang sudah ditentukan untuk kembali suntik dan suami bekerja diluar kota, jadi ibu melakukan KB pada saat suaminya akan pulang saja.(11)

Hal ini sejalan dengan penelitian yang dilakukan oleh Amalia (2012) yang menunjukkan pada tindakan yang dilakukan dalam penanganan efek samping kontrasepsi suntik 3 bulan oleh ibu primipara bahwa tindakan yang ibu lakukan untuk mengatasi efek samping KB suntik 3 bulan yaitu tiduran atau istirahat mengatasi sakit kepala.(12) 
Menurut asumsi penelitian bahwa ada hubungan sikap dan tindakan ibu dengan perubahan siklus menstruasi. pengalaman adalah suatu kejadian yang pernah dialami seseorang dalam berinteraksi dengan lingkungannya. Adanya kecenderungan pengalaman yang kurang baik akan berusaha dilupakan seseorang. Namun jika pengalaman dengan objek tersebut menyenangkan, maka secara psikologik akan timbul kesan yang sangat mendalam dan membekas dalam emosi kejiwaannya, dan akhirnya dapat membentuk sikap yang positif dalam kehidupannya.

Padahal semakin lama menggunakan $\mathrm{KB}$ suntik seharusnya ibu menjadi lebih paham dan sudah dapat mengatasi efek samping. Menurut peneliti, sikap ibu yang negatif terhadap efek samping KB suntik 3 bulan dapat dipengaruhi oleh pengalaman terdahulu yang tidak meninggalkan kesan baik.(13)Mereka memilih tidak peduli, bersikap acuh, dan tidak mau menerima

\section{KESIMPULAN}

Hasil analisis data
menggunakan uji Chi-square dan pembahasan yang telah dilakukan mengenai Hubungan Sikap Dan tindakan Ibu Pengguna KB Suntik 3 Bulan Dengan Perubahan Siklus Menstruasi dapat di simpulkan memperlihatkan ada hubungan signifikan antara sikap ibu dengan perubahan siklus menstruasi dan ada hubungan signifikan antara tindakan ibu dengan perubahan siklus menstruasi. Sebagai bahan masukan kepada Klinik Hj dermawati Tahun 2017 sehingga dapat di lakukan pelayanan kesehatan yang lebih baik lagi khususnya kepada ibu pengguna KB suntik 3 bulan.

\section{KEPUSTAKAAN}

1. Rohmatika D, Prabandari F. Pengaruh Usia Menarche Terhadap Usia Menopause Pada Wanita Menopause Di Desa Jingkang atau berusaha untuk mengatasi masalah efek samping yang dialaminya. Sikap dapat berubah dengan diperolehnya tambahan informasi. Dengan pengetahuan yang cukup maka semakin positif sikapnya. Banyak ibu yang menggunakan KB suntik 3 bulan sudah mendapatkan informasi tentang efek samping dari KB suntik 3 bulan. Tapi masih banyak juga ibu yang bersikap negatif. Kurangnya aktifitas seperti membaca koran, majalah, menonton televisi/berita terutama tentang kesehatan menyebakan masih bnyak ibu yang menggunakan $\mathrm{KB}$ suntik 3 bulan yang bersikap negatif terhadap efek samping yang dialaminya. Selain itu interaksi dengan orang yang dianggap penting juga mempengaruhi sikap ibu yang memakai KB suntik 3 bulan. Kurangnya pemahaman tentang penjelasan efek samping yang dilakukan tenaga kesehatan dapat mempengaruhi sikap ibu yang mengalami efek samping $\mathrm{KB}$ suntik 3 bulan.

Babakan Kacamatan Ajibarang Kabupaten Banyumas Tahun 2012. Bidan Prada J Publ Kebidanan Akbid YLPP Purwokerto. 2012;3(2).

2. Ekawati D. Pengaruh KB suntik DMPA terhadap peningkatan berat badan di BPS Siti Syamsiyah Wonokarto Wonogiri. 2010;

3. Nuraini T, Kusmana D, Afifah E. Injection of Carica papaya L. Seed Extract of Cibinong Variety to Macaca fascicularis L. and its Effect to Quality of Spermatozoa and Level of Testosterone Hormone. Makara J Heal Res. 2012;9-16.

4. Barat DKPS. Profil Kesehatan tahun 2014. Padang Sumatera Barat. 2015;

5. Fakhidah LN. Hubungan Lama Penggunaan Kontrasepsi Suntik 3 Bulan dengan Kejadian Keputihan Di Bidan Praktek Swasta Fitri Handayani Cemani Sukoharjo. Maternal. 2016;10(10). 
6. Fitriana F, Kunsianah K. Hubungan Pemakaian Kontrasepsi Suntik Tiga Bulan Dengan Kejadian Amenorhea Sekunder Pada Akseptor Kb Suntik Di Desa Jatisari Kecamatan Subah Kabupaten Batang. ILMU Kesehat. 2016;7(1):1-9.

7. Susilowati E, SiT S. KB Suntik 3 (Tiga) Bulan dengan Efek Samping Gangguan Haid dan Penanganannya. Maj Ilm Sultan Agung. 2019;49(123):40-51.

8. Kinesti N. Sikap Ibu Terhadap Efek Samping Kb Suntik 3 Bulan Di Desa Bakalanrayung Kecamatan Kudu. J Metab Vol 2 No 2 April 2013. 2015;2(2).

9. Kasdu D. Solusi problem wanita dewasa. Niaga Swadaya; 2005.

10. Wulandari FW. Asuhan Kebidanan Komprehensif Kehamilan, Persalinan, Nifas, Bayi Baru Lahir, Dan Masa Antara (Keluarga Berencana Suntik Depoprogestin) pada NY. S umur 33 tahun g3p2a0 di Kabupaten Banjarnegara. Universitas MuhammadiyAH Purwokerto; 2014.

11. Luthvi Mayasari D. Hubungan Tingkat Pendidikan Dengan Tingkat Pengetahuan Akseptor Tentang Efek Samping Kb Suntik Dmpa 150mg Di Pustu Desa Madusari Kecamatan Siman Kabupaten Ponorogo. Universitas Muhammadiyah Ponorogo; 2015.

12. Amalia b. Asuhan Kebidanan Komprehensif Pada Kehamilan, Persalinan, Nifas Bayi Baru Lahir $(\mathrm{Bbl})$, Dan Perencanaan Keluarga Berencana $(\mathrm{Kb})$ Pada Ny y umur 26 tahun G2p1a0 di Puskesmas Banyumas. Universitas Muhammadiyah Purwokerto; 2016.

13. Detiana P. Hamil Aman dan Nyaman di Atas 30 Tahun. Media Pressindo; 2010. 
